\title{
LESSONS LEARNED FROM THE MID-TERM EVALUATION OF THE AUSTRIAN NATIONAL STRATEGY FOR THE FRUIT AND VEGETABLES SECTOR
}

\author{
Josef Hambrusch ${ }^{1}$, Nina Weber ${ }^{2}$
}

\begin{abstract}
Summary
The Austrian national strategy for the fruit and vegetable sector provides a framework for the producer organisation's sustainable operational programmes. One main objective of the national strategy is the bundling of production in order to improve the competitiveness of the fruits and vegetables producers. According to the agricultural census 2010, the share of production value of producer organisations in the fruit and vegetables sector, has constantly risen since 1999 and amounted to 53\% in 2010. When analysing the number of projects and the expenditure of funds, it was found that a majority of financial resources was invested into the improvement of marketing activities / conditions and product quality. In order to justify ongoing public support in future, it will become necessary to stress the benefits of the operational programmes for the general public. This could be achieved, for example, by focusing on environmental measures. Already, integrated production has become the standard production method in the sector. Other environmental measures within the national strategy aimed at the reduction of resources in production (such as pesticides or energy). For these measures no improvements could be measured due to lacking monitoring data. For future evaluations, indicators need to be defined more clearly and precisely, in order to make the achievement of objectives measurable and visible.
\end{abstract}

Key words: fruit and vegetable sector, producer organisations, national strategy, operational programmes.

JEL: $Q 180$

1 Josef Hambrusch, M.Sc., scientist at the Federal Institute of Agricultural economics, Marxergasse 2, 1030 Vienna, Austria, Phone: 00438773651 7436, E-mail: josef.hambrusch@awi.bmlfuw.gv.at

2 Nina Weber, M.Sc., scientist at the Federal Institute of Agricultural Economics, Marxergasse 2, 1030 Vienna, Austria, Phone: 00438773651 7437, E-mail: nina.weber@awi.bmlfuw.gv.at 


\section{Introduction}

Pursuant to Articles 125 and 127 of Regulation (EU) No. 543/2011, the EU Member States' national strategies for "sustainable operational programmes in the fruit and vegetable sector" must be subject to evaluation (Durchführungsverordnung (EU), Nr. 543/2011). The purpose of this evaluation is to examine the degree of utilisation of financial resources and to assess the effectiveness and efficiency of the implemented operational programmes. Furthermore, the programmes' impacts and results shall be evaluated against the predefined objectives laid down in the national strategy, and, if applicable, also against the objectives set out in Article 103c, paragraph 1 of regulation (EC) No. 1234/2007 (Verordnung über eine gemeinsame Organisation der Agrarmärkte und mit Sondervorschriften für bestimmte landwirtschaftliche Erzeugnisse Verordnung über die einheitliche GMO (EG), Nr. 1234/2007). In accordance with the implementation of the Austrian national strategy, the evaluation includes the period 2009, 2010 and 2011.

The Austrian national strategy for the fruit and vegetable sector aims to set its objectives according to the heterogeneous structures of Austrian producer organisations. For this purpose it defines a framework of six guidelines, which outline the main targets whilst additionally offering flexibility for the individual strategies of the producer organisations. Furthermore, these guidelines follow the overarching EU-objectives and guarantee coherency with other national schemes (BMLFUW - Bundesministerium für Land und Forstwirtschaft, Umwelt und Wasserwirtschaft, 2009).

During the evaluated period between 2009 and 2011, ten authorised producer organisations (POs) existed in Austria and were investigated in the course of the evaluation. Of these investigated producer organisations, four operated in the fresh vegetable sector, two in the fruit sector, one in the combined fruit and vegetable sector, one in the field of fruit, vegetables and processed products, and two in the processed products sector. Two of the investigated producer organisations were authorised in the course of the evaluated period. In the year 2011, three producer organisations intensified their existing cooperation and established an association of producer organisations with a focus on convenience products. Because of the date of its establishment, this association of producer organisations is not subject to the present evaluation (Jahresberichte der österreichischen Erzeugerorganisationen, 2009, 2010, 2011), (Schlussberichte der österreichischen Erzeugerorganisationen, 2011), (Halbzeitevaluierungen der österreichischen Erzeugerorganisationen, 2011).

\section{Methods}

For this evaluation study, quantitative methodologies (statistical analyses) were combined with qualitative methods (interviews, "world café" in workshops). The monitoring reports of the Austrian producer organisations, which were forwarded by the BMLFUW (Federal Ministry of Agriculture, Forestry, Environment and Water Management), served as the fundamental data basis. Complementary secondary 
statistical data sources (e.g. Statistics Austria, Agrarmarkt Austria (AMA) and FADN data) were also used, and additional information was acquired through qualitative interviews. The interviews were conducted with representatives of almost all (nine of ten) producer organisations, as well as with representatives of the decision making and supervisory authorities of the operational programmes, advisory bodies and the Austrian Chamber of Agriculture. Furthermore, valuable inputs and conclusions were gathered through participation in a seminar on "biodiversity in fruit production" and two self-organised workshops.

The results of the evaluation are limited by several restrictions and should therefore be interpreted with commensurate caution. These restrictions include some inconsistency of the received data with regard to the definition or calculation of certain indicators (such as the indicator for production costs) and the plausibility and comprehensibility of the same. In addition, the effects of implemented measures generally only show after several years. For this reason, the effects of measures implemented during the evaluation timeframe (2009 to 2011) can really only be assessed in 2014, after the end of the present national strategy. To further complicate matters, the monitoring reports on which the evaluation was based assume that single actions taken under the fruit and vegetable regime can be assigned to individual measures (according to reason). But, in fact, many of the actions grouped under a single specific measure are interrelated and furthermore show strong linkages to, as well as influences on, numerous other and different measures as well. This makes it impossible to attribute certain effects to only one implemented measure - instead, the actions of the operational programmes work together as a whole.

\section{Results and discussion}

The importance of the single measures of the national strategy is reflected by the distribution of operational funds, which amounted to around 44 million Euros between 2009 and 2011(Figure 1). 96\% of the total invested operational funds were distributed amongst four measures: "marketing" (48\%), "product quality" (22\%), "environmental measures" (15\%) and "production planning" (11\%). The remaining four percent were distributed amongst the measures "crisis prevention and management," "research" and "other actions" (Halbzeitevaluierungen der österreichischen Erzeugerorganisationen, 2011). The measure for crisis prevention and management gained more importance in the year 2011 during the EHEC crisis, as a result of the temporarily valid regulation (EU), No. 585/2011 (Durchführungsverordnung (EU), Nr. 585/2011, 2011). 
Figure 1. Distribution of operational funds

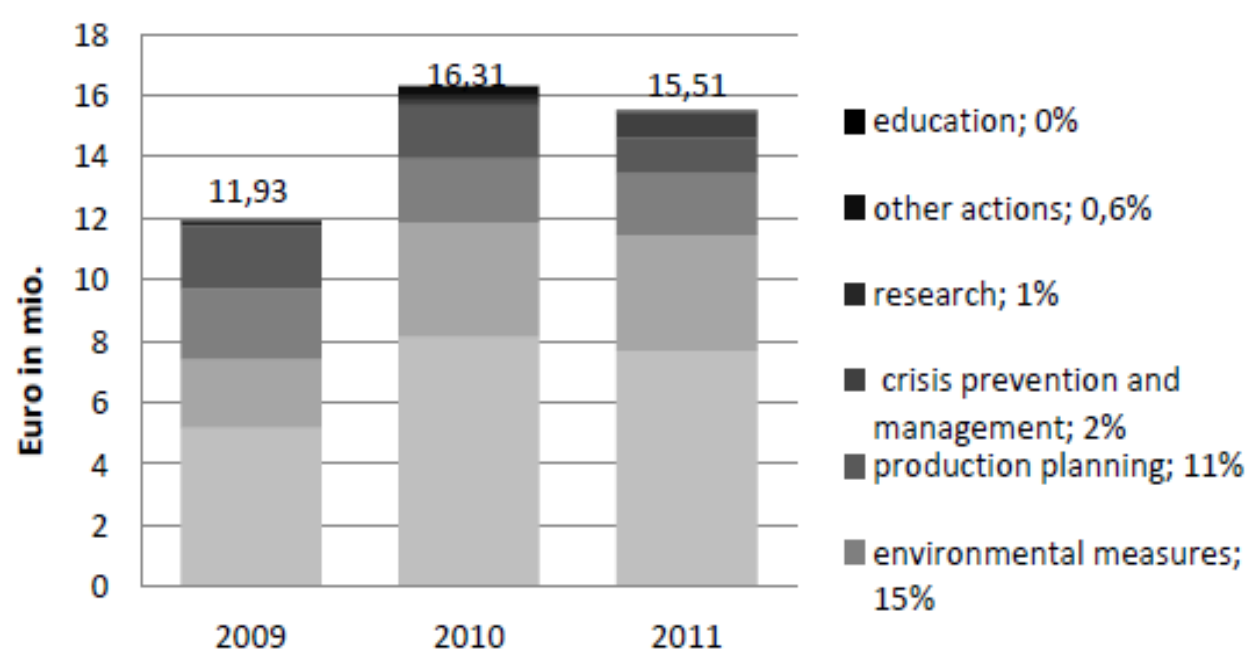

Source: Adapted from: Annual reports of the Austrian producer organisations 2009, 2010, 2011.

Due to the recently recognised producer organisations the total area of members increased by $45 \%$ between 2007 and 2011 to 10,325 hectares. Compared to the number of members, the total agricultural area of producer organisations showed a stronger increase, which lead to a slight increase of area per member (4.84 hectares per member on average). On average, farms in the vegetable sector grew larger in size during the evaluation period than did farms in the fruit sector (Halbzeitevaluierungen der österreichischen Erzeugerorganisationen, 2011).

The concentration rate evolved similarly to the development of producer organisations and their members. Since the first producer organisations were established, the degree of concentration for commercial fruit and vegetable production has risen to about $60 \%$ (Halbzeitevaluierungen der österreichischen Erzeugerorganisationen, 2011), (Statistik Austria, 2012).

The decision whether or not an agricultural holding becomes a member of a producer organisation is a very individual choice. For many producer organisations and agricultural holdings their historical development and origin still play a major part. Thus, production and marketing structures reflect the developments of the past and many farmers were already suppliers to predecessor organisations before the producer organisations were established. In addition, fruit and vegetable crops traditionally marketed directly (e.g. strawberries and asparagus) are underrepresented in Austrian POs. In general, the collective marketing of products aims to secure product turnover in the long term. Depending on the type of marketed product (fresh products, processed products, fruit or vegetables), the POs also have to face international competition. According to the interviews, POs offer a relatively safe market outlet for their members during a year with a supply surplus. On the other hand, during a year with a market supply shortage some producers believe they can sell their produce at better 
conditions on their own. In this context, membership in a PO is also a decision connected to "speculation" and risk aversion, as ups and downs in the markets can be "smoothed over" from year to year.

In the meantime, many producer organisations already have their own specialised consultants for members. This service offers additional motivation for farmers to become members of a PO, and consultancy services related to product quality and production techniques (e.g. varietal conversion) are viewed as particularly beneficial by agricultural holdings. Another major benefit of producer organisations is the opportunity for collective purchases, although this effect cannot be solely attributed to the impact of the operational programmes and national strategy.

At the same time, interviews show that farmers frequently are not aware of the benefits of producer organisations. Producer organisations are often regarded as "abstract constructions" and their investments are not perceived as directly beneficial to the individual farm. Therefore, the internal communication within a producer organisation plays a key part in guaranteeing transparency and communicating important information to members. However, the internal communication of Austrian producer organisations does not always rate as satisfactory. The interviews also reveal that, alongside "internal marketing" measures, more attention should be paid to motivating new members to join. In general, it can be stated that producer organisations are not always successful in transparently displaying the benefits of participation to farmers. In addition to economic rational, inter-human relationships play a key part in the decision regarding participation in a PO. By now, retailers have also developed strategies to counter the cooperation of producer organisation and POs have to deal with these strategies. One such strategy involves separating producers from POs and integrating them in the retailer's own supply chains (Österreichische Erzeugerorganisationen, Interessensvertretungen, Expertinnen, 2012).

\section{Contribution of the national strategy to the overall competitiveness of fruit and vegetables producers}

One of the most important functions of POs is the concentration of supply, which should lead to a better bargaining position for producers in the face of large retailers. According to the interviews, the opportunities of POs to positively influence fruit and vegetable prices are rated as quite modest by the interviewed stakeholders (Österreichische Erzeugerorganisationen, Interessensvertretungen, Expertinnen, 2012). During the investigated period (2009 - 2011) all of the Austrian POs implemented measures to promote product quality. Improvements in quality management systems, stronger merchandise controls, certification processes and audits all aim to meet the increasingly stringent demands. In addition, integrated production methods have become the standard production system in the Austrian fruit and vegetable sector (Österreichische Erzeugerorganisationen, Interessensvertretungen, Expertinnen, 2012) (Halbzeitevaluierungen der österreichischen Erzeugerorganisationen, 2011), (Figure 2). 
Figure 2. Development of organic and integrated production in the producer organisations in Austria

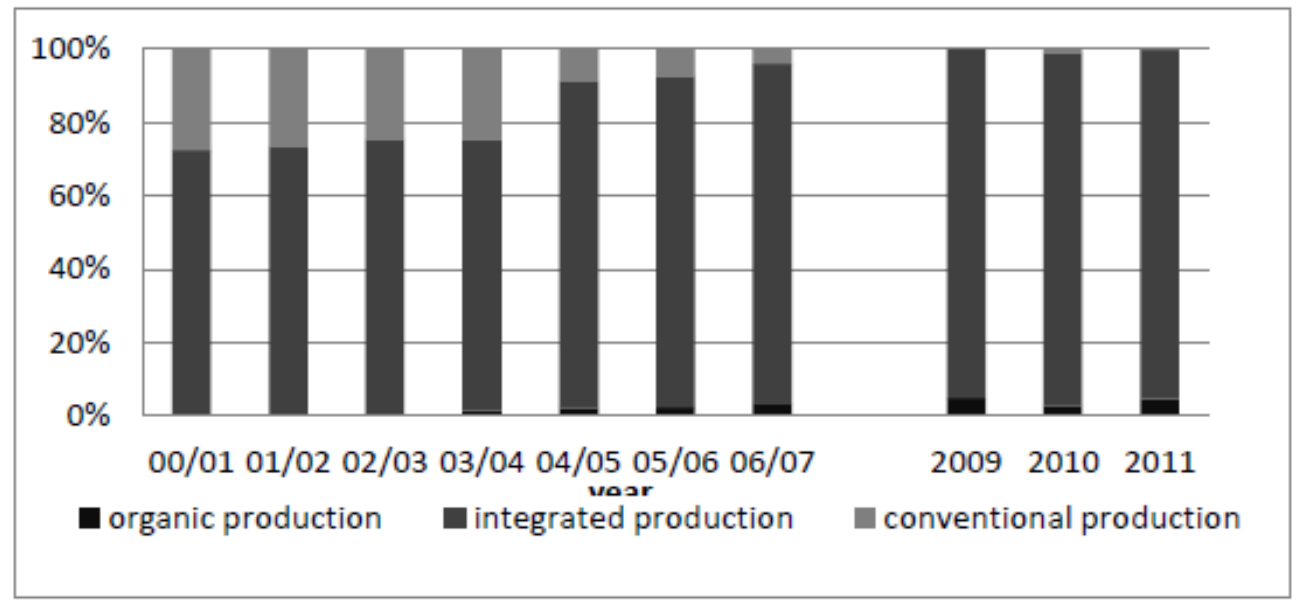

Source: Adapted from: Annual reports of the Austrian producer organisations 2009, 2010, 2011; Hambrusch, Quendler, 2008.

Under the national strategy POs have aimed their actions at keeping internal production costs as low as possible. Among other costs, labour costs make up the major cost factor for POs. It can also be concluded that, within the operational programmes, investments in technical facilities lead to a more efficient utilisation of labour and therefore contribute to higher labour productivity.

When regarding costs at the level of individual farms, energy and labour costs make up the major portion of the production costs. Under consideration of historical developments (e.g. energy price index) it can be concluded that the input costs are due to rise further in future. According to interviews, membership in a PO offers the possibility of joint purchases and therefore opportunities to lower costs for intermediate consumption (fertiliser, seeds etc.) through quantity discounts and special conditions (BMLFUW - Bundesministerium für Land und Forstwirtschaft, Umwelt und Wasserwirtschaft, 2008) (LFL - Bayerische Landesanstalt für Landwirtschaft, 2012) (LK - Landwirtschaftskammer Wien, 2012).

\section{Deadweight effects of the national strategy}

Deadweight effects were estimated using qualitative interviews with experts representing the POs. The experts had to rate on an ordinal scale whether the implemented actions would have been carried out even without support of operational funds. Altogether, 64 interview statements were collected. Of these statements, 33 declared that the implemented actions would not have been carried out without funds from the operational programmes; in contrast, in 31 cases the actions would have been taken even without funding. When taking a closer look at the single measures, the experts estimated that actions aimed at "planning and production", "product quality" and "marketing" predominated among those that would have been carried out even without the aid of funds. This leads to the conclusion that actions related to the mentioned measures are seen as crucial for sustainable competitiveness. In 
addition, investments must be made in order to maintain and improve internal processes inside the producer organisations. As a result, expenditures on these measures comprise roughly $80 \%$ of the total expenditures of the operational funds between 2009 and 2011 . In contrast, the funds of the operational programmes play a major part in implementing the measures "research and experimental production," "crisis prevention and management" and "environmental measures." Without funding through the operational programmes, actions for these measures would only have been carried out in a minority of the cases (Österreichische Erzeugerorganisationen, Interessensvertretungen, Expertinnen, 2012).

\section{Coherence between different measures of the national strategy - and between the national strategy for the fruit and vegetables sector and the Austrian rural development programme}

For this evaluation study, coherence between the different measures within the operational programmes is assessed. At the same time, however, the coherence between the operational programme measures and the measures of the rural development programmes must also be considered.

\section{Measures of the operational programmes}

Coherence between the measures of the operational programmes can be rated as satisfactory. According to the mid-term evaluation reports and annual monitoring reports of the POs, in combination with an expert appraisal, it can be concluded that the actions and measures of the programmes complement each other in achieving their objectives. In many cases, synergies can be identified between individual measures (Jahresberichte der österreichischen Erzeugerorganisationen, 2009, 2010, 2011), (Österreichische Erzeugerorganisationen, Interessensvertretungen, Expertinnen, 2012), (Halbzeitevaluierungen der österreichischen Erzeugerorganisationen, 2011).

\section{Rural development programme}

Beneficial linkages between the measures implemented through the operational programmes and the measures implemented through the rural development programme can be found in axis 1 (improving the competitiveness of agriculture and forestry) and axis 2 (improving the environment and countryside) of the Austrian rural development programme. The Austrian programme for rural development excludes POs from investments at the level of agricultural holdings. Exceptions are only made for collective purchases which are not considered within the rural development programme. Coherence and complementarity of the operational programmes for fruit and vegetables are guaranteed by the granting and controlling bodies. The responsible authorities have a comprehensive overview of the planned actions and ensure coherence in implementation. The Austrian paying agency (AMA) plays a central part in this process. AMA conducts administrative scrutiny of the payments to producer organisations. Because of the relatively small number of authorised POs in Austria, an on-the-spot check is conducted with each final payment. A central focus is on thoroughly checking invoices to ensure they are eligible for funding. Furthermore, the responsible controllers for both the fruit and vegetable operational programmes and the rural 
development programmes work in cooperation to exchange information. Due to the double checking of applications, both for the fruit and vegetable operational programmes and the rural development programme, double payments can be excluded. The POs also have to contractually declare that they do not receive any form of double payments and this is an integrative part of the operational programmes. According to the granting and controlling authorities, there were almost no issues related to double payments during the evaluated period in Austria (Österreichische Erzeugerorganisationen, Interessensvertretungen, Expertinnen, 2012).

\section{Relevance of subsidies for the general public and effectiveness of measures}

The number of implemented actions and the amount of invested resources per measure indicate that the major portion of funds was invested in improving marketing conditions and product quality. These objectives mainly pursue the specific interests of the POs (such as improving competitiveness and the concentration of supply). To justify future public support, it will become of vital importance to also demonstrate the public benefits of implemented measures. In this way, operational programmes add value to general public objectives through their effects. For example, improved product quality and food safety can be seen as benefiting the public good. This may refer to special production requirements or the traceability of various products.

Up to now, approximately $90 \%$ of production is certified by some kind of private quality management system. This development not only occurs within producer organisations, but also within the entire fruit and vegetable sector in Austria.

Another important aspect pertains to environmental measures. Integrated production has become a generally accepted production standard in the entire fruit and vegetable sector. Despite discussions on the effectiveness of integrated production and the role of customers (retail), it can be concluded that the requirements for integrated production has positive effects on the environment. For other environmental actions aimed at reducing soil and water contamination, it was not possible to evaluate the effects due to insufficient quality of the recorded indicators (Halbzeitevaluierungen der österreichischen Erzeugerorganisationen, 2011).

Therefore, in future, producer organisations should define uniform and clear indicators to allow accurate and precise interpretation as well as evaluation according to predefined objectives.

\section{Efficiency of the national strategy}

Conclusions regarding administrative effort have been derived from the expert interviews and comprise the opinions of different actors. In general, producer organisations are satisfied with the current design of the national strategy and operational programmes. Points of criticism concern the financial and personnel-related bureaucratic burden related to the administration, implementation and scrutiny of measures. In most POs one parttime employee is in charge of administrative duties related to the operational programmes. 
Furthermore, in most POs the reporting system is conferred to an external consultancy. The small-scale and rather heterogeneous structure of Austrian POs leads to higher administrative costs and operating expenses (for the POs). According to the interviews, specifications and controls are much costlier for POs than for individual farms. From the perspective of costs, there is little incentive for farms to join a producer organisation (e.g. to contribute to operational funds and the internal costs of EOs). Consequently, POs develop new internal concepts to confront this issue. Fruit POs, for example, try to meet this problem by changing and developing their fruit varieties. The reduction of varieties in particular should satisfy changing demand and help meet logistical challenges more effectively (Österreichische Erzeugerorganisationen, Interessensvertretungen, Expertinnen, 2012).

The implemented measures often include investments in facilities and equipment which increase the internal performance of production. Many of the implemented measures show a connection with improving marketing conditions (roughly $50 \%$ of the operational funds). In compliance with the legal framework, actions affecting individual farms have been implemented to a smaller extent (e.g. battery operated shears), (Halbzeitevaluierungen der österreichischen Erzeugerorganisationen, 2011). It can be assumed that these types of actions raise the satisfaction of members, and that they may implicate some deadweight effects (to a certain extent).

Alongside POs, several institutions are involved with the implementation, administration and control of the operational programmes. These institutions in general include departments of the BMLFUW (Federal Ministry of Agriculture, Forestry, Environment and Water Management), which are entrusted with scrutiny of the legal requirements and authorising the contents of the operational programmes. Additionally, preliminary operational funds are approved. The AMA (Agrarmarkt Austria) is the paying agency and is entrusted with the handling of payments and controlling the implementation of the operational programmes. It is difficult to estimate the costs for the above mentioned administrative activities. Nevertheless, the number of involved institutions and staff suggests that the co-financed funds by far cover the expenses.

\section{Conclusions}

The following subsection summarises several important results, as well as proposals for adapting the measures of the operational programmes and the national strategy, as given by interviewees and derived from the available data (Österreichische Erzeugerorganisationen, Interessensvertretungen, Expertinnen, 2012), (Halbzeitevaluierungen der österreichischen Erzeugerorganisationen, 2011).

Concerning the number of Austrian POs, a certain degree of saturation seems to have been reached. POs exist in most regions which are relevant for fruit and vegetable production (Figure 3). A higher number of POs probably would be able to increase the degree of concentration but, on the other hand, the intended concentration of supply would become weakened. Because the POs stand in competition with each other, a higher number would enable retailers to play the POs off against one another. In contrast, a certain potential can be 
found in cooperation and team play between individual POs. Accordingly, incentives should be created for stimulating closer cooperation between POs on a national level and to support the establishment of associations of producer organisations. Under consideration of the ongoing structural changes in agriculture, it will be the task of the POs to maintain existing structures (number of members) and/or gain new members.

Figure 3. Distribution of producer organisations throughout Austria in 2011

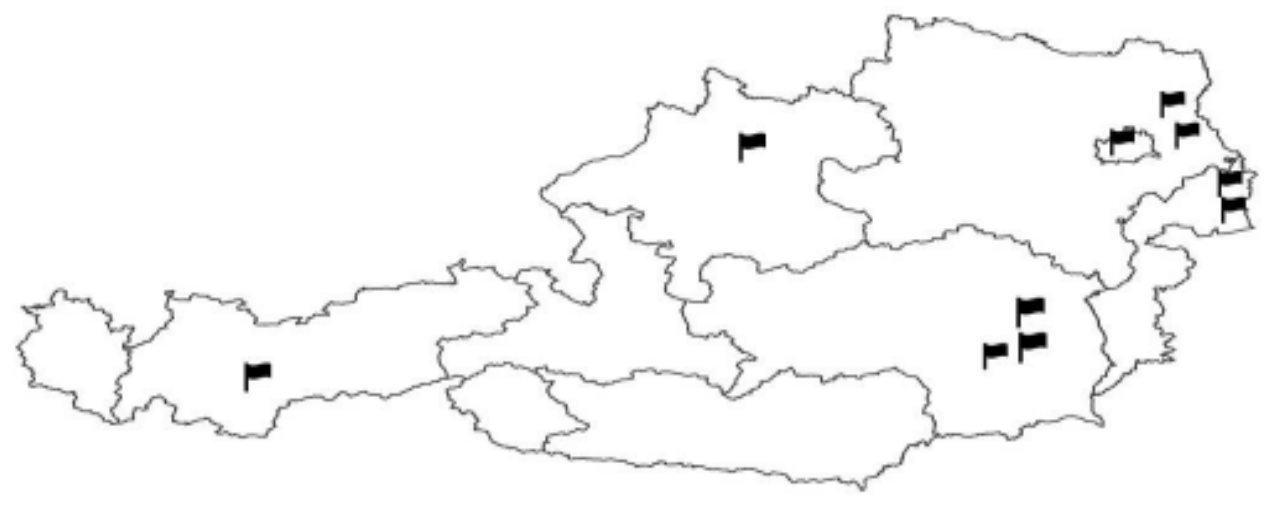

\section{Location of producer organisation}

Source: Adapted from: Annual reports of the Austrian producer organisations 2009, 2010, 2011.

Future challenges appear to emerge from the increasing concentration of large retailers and discounters, who together make up the major distribution channels. This situation calls for the development of new concepts and strategies by the producer organisations. Especially in POs without a contracted marketer (single-level POs) additional sales training for the sales personnel could improve the bargaining position in the face of professional counterparts. Furthermore, in reference to consumer surveys and studies, consumers are increasingly demanding a higher level of services (e.g. convenience services) and are also growing more concerned about quality and food safety. Regarding these trends, the national strategy should focus on measures which support the development of new concepts as well as innovation capacity (e.g. alternative marketing possibilities).

In order to be able to evaluate the sustainability of POs and/or their operational programmes an indicator should be introduced which analyses the duration of PO membership. This indicator could for example determine the ratio of those farms whose membership in a PO has lasted longer than five years. If this ratio is very small, it can be concluded that the POs' sustainability is rather poor. In this case individual farms could draw an advantage from membership in the short run and then leave the producer organisation.

Some POs expressed a demand for an extension of support measures to individual farms within the operational funds. Depending on the final design of the CAP $(2014-2020)$ a clear differentiation between the measures of operational funds and those of the Rural Development Programmes should be ensured (e.g. maximum limit of investments). One 
problem regarding delimitation between measures of the operational programmes and rural development measures concerns the different planning periods (at least this has been the case in the past). This complicates the definition and design of measures within the operational programmes (e. g. environmental measures) but also the coordination and interlinking of such measures with those of the rural development programme. A recommendation which concerns the national level as well as the European level would be to synchronise/coordinate the planning horizons of the operational programmes and the rural development programmes to the highest possible degree.

Mirroring the on-going discussion regarding a readjustment of the Common Agricultural Policy (CAP), the question arises as to what content might be supported by operational programmes in the coming period. Depending on the design of the CAP, one suggestion involves measures for risk prevention and crisis management. In this regard, it should also be clarified why such measures did not receive more consideration during the current period. Due to the low utilisation rate for risk prevention (e.g. mutual funds, insurances), it can be assumed that the priorities simply lay on other measures during the current period. However, another possibility is that the design of these measures was not attractive enough. The energy sector represents another potential option for granting support (e.g. technical investments in more efficient equipment and alternative energy sources). Given the relatively high energy costs in production, as well as the high energy inputs in protected cultivation systems, it seems reasonable to more closely consider promoting alternative energy concepts. In the course of the expert interviews, several different sub-measures were mentioned that could be implemented complementary to already existing environmental measures. For instance, these include conversion to production systems with closed water circulation, greater promotion of the use of beneficial organisms and supporting the use of plant fortifiers.

In the course of a workshop, experts expressed their concern about the EU thresholds pertaining to investments in environmental actions (reduction of water use, energy use or the emission of pollutants). Specifically, they expressed that a $25 \%$ improvement in the initial situation was not realistic in Austria, given the country's already high environmental and production standards. For this reason, it seems nearly impossible to accomplish such a high improvement rate; and hence a discussion on adopting prescribed thresholds based on the existing environmental standards in individual member states was proposed. Such an adoption would enable appropriate actions to be authorised and supported more frequently in Austria.

\section{Literature}

1. BMLFUW - Bundesministerium für land und forstwirtschaft, umwelt und wasserwirtschaft (2008): Deckungsbeiträge und Daten für die Betriebsplanung 2008, Eigenverlag, Wien.

2. BMLFUW - Bundesministerium für land und forstwirtschaft, umwelt und wasserwirtschaft (2009): Nationale Strategie - operationelle Programme Erzeugerorganisationen - Sektor Obst und Gemüse Österreich, BMLFUW - Abteilung III 10, Wien. 
3. Durchführungsverordnung(EU) NR. 543/2011, Verordnung - Europäische Kommission, Brüssel, Nr. 543/2011, 2011.

4. Durchführungsverordnung(EU) NR. 585/2011, Verordnung - Europäische Kommission, Brüssel, Nr. 585/2011, 2011.

5. Halbzeitevaluierungen der österreichischen erzeugerorganisationen: Beerenobst (2011), efko (2011), etg (2011), geo (2011), oberinntal obst (2011), opst (2011), steirisches gemüse (2011), Eigenverlag. s.l.

6. Hambrusch, J., Quendler, E. (2008): Teilanalyse der österreichsichen Obst- und Gemüsewirtschaft, Arbeitsbehelf, Nr. 28, BA für Agrarwirtschaft, Wien.

7. Jahresberichte der österreichischen erzeugerorganisationen: Beerenobst $(2009,2010)$, efko (2010, 2011), eom $(2009,2010,2011)$, etg $(2010,2011)$, geo $(2009,2010,2011)$, $\operatorname{lgv}(2009,2010,2011)$, oberinntal obst $(2009,2010,2011)$, opst $(2009,2010,2011)$, $\operatorname{sgv}(2009,2010,2011)$, steirisches gemüse $(2009,2010,2011)$, Eigenverlag, s.l.

8. LFL - bayerische landesanstalt für landwirtschaft (2012): LfL Deckungsbeiträge und Kalkulationsdaten für Feldgemüse, available at: www.stmelf.bayern.de/idb

9. LK - landwirtschaftskammer Wien (2012): Kalkulationsunterlagen für die Gemüseproduktion im geschützten Anbau (Strauchtomaten, Cherry-Tomaten, Paprika, Gurken), Schriftliche Mitteilung, September 2012.

10. Österreichische erzeugerorganisationen, interessensvertretungen, expertinnen (2012): Interviews - mündliche Mitteilungen von 16.08.2012 bis 28.08.2012.

11. Schlussberichte der österreichischen erzeugerorganisationen: eom (2011), lgv (2011), sgv (2011), Eigenverlag, s.l.

12. Statistik Austria (2012): Landwirtschaftliche Gesamtrechnung, Wien, available at: $\quad$ www.stat.at/web_de/statistiken/land und forstwirtschaft/gesamtrechnung/ landwirtschaftliche_gesamtrechnung/index.html - Juli 2012)

13. Verordnung über eine gemeinsame organisation der agrarmärkte und mit sondervorschriften für bestimmte landwirtschaftliche erzeugnisse - verordnung über die einheitliche gmo (eg) nr. 1234/2007, Verordnung - Europäische Union, Brüssel, Nr. $1234 / 2007$. 